\title{
Ofrenes smerte, seernes ubehag - etiske utfordringer i katastrofenyheter
}

\section{Soilikki Vettenranta}

Etiske spørsmål knyttet til krise- og katastrofenyheter diskuteres som regel $i$ forhold til personvern og journalistiske overtramp. Det er journalistenes utøvelse av sin profesjon i en katastrofesituasjon, og spesielt konsekvensene for ofre og pårørende, som har voert i fokus $i$ den etiske debatten $i$ Norge. Denne artikkelen ser normere på to etisk utfordrende forhold med eksempler fra utvalgte katastrofenyheter. På den ene siden drøftes det hvordan økt personfokusering og noerhetskravet som journalistisk nyhetskriterium bidrar til at mennesket kan bli misbrukt for å øke seertallene. Økt kommersialisering tvinger mediebedriftene til å ta i bruk dramaturgiske midler som kan true integriteten til de involverte i nyhetssendinger. På den andre siden diskuteres det, på grunnlag av resepsjonsforskningen, på hvilken måte publikum kan oppleve den journalistiske dramaturgien krenkende i katastrofenyhetene. Som teoretisk grunnlag vurderes Levinas og Løgstrups norhetsetikk, som medieforskerne $i$ Norge har brukt som en etisk rettesnor for å ivareta enkeltmenneskets krav på respekt $i$ katastrofenyheter. I denne artikkelen hevdes det at noerhetsetikken kommer til kort i en kommersiell, fiksjonalisert og teknisk avansert nyhetsproduksjon. Det foreslås også hvordan enkeltmennesker kan presenteres mer etisk ansvarlig i katastrofenyheter.

Nøkkelord: katastrofenyheter, medieetikk, nærhetsetikk, Vær varsom-plakaten

\section{Innledning}

Den engelske medieetikeren Matthew Kieran (1998) hevder at journalistikken tjener medieindustrien der økonomiske mål dominerer, og der det er lite rom for etikk, uavhengig av journalistenes egen vilje og motiver. Medie- 
industrien ligner hvilken som helst industri der profittbegjær, salgstall, publikumstall og annonsørenes behov ligger til grunn, selv om deler av nyhetsformidlingen fremdeles i teorien er tuftet på public service-ideen. Oppfatningen om medieetikkens kår er ikke like dyster i Norge som i andre deler av verden. De etiske problemstillingene har fătt økende interesse både i den offentlige debatten, blant journalister, medieforskere og publikum. Nyheter etter omfattende menneskeskapte ulykker, naturkatastrofer og kriminalsaker, spesielt der barn har vært ofre, har aktivisert denne diskusjonen. Medieforskerne Svein Brurås (2005; 2006), Audgunn Oltedal (2006; 2007), Terje Rasmussen (2001; 2007), Lars Arve Røssland (2007) og Odd Raaum (1986), mange med journalistbakgrunn, har vært viktige premissleverandører til denne diskusjonen.

Begrepet medieetikk kan forstås nokså vidt, som en etikk for medieinstitusjonenes totale funksjon og rolle i samfunnet. Da omfatter den alle sider ved mediesystemet, fra den nye teknologien til offentlig mediepolitikk, maktdimensjonen, publikums bruk av medier og programtilbudet (Brurås 2006). Vanligvis diskuteres medieetikken knyttet til enkeltsaker, og nyheter er stoff som oftest settes under den etiske lupen. Kritikken av nyhetsformidlingen fra store ulykker og katastrofer har primært vært rettet mot måten intervjuer er gjennomført på, ved det overdrevne omfanget og manglende empati overfor ofre og pårørende. Men det er ikke bare personene vi ser på skjermen som krenkes, også publikum kan føle vemmelse og avsky etter reportasjer. Filosof Arne Johan Vetlesen (2007) hevder at etikkens kjerne henger sammen med begått urett. Den er knyttet til fornemmelsen av at noe er "galt», at det foregår en krenkelse som trigger en trang til å gripe inn i situasjonen. Resepsjonsforskningen av nyheter (Healey 2000; Nightingale et al. 2000; Vettenranta 2005) tyder på at publikum stadig oftere får denne fornemmelsen av en krenkelse, at et menneske på skjermen har vært utsatt for urett og ydmykelse.

I denne artikkelen avgrenser jeg etikkfeltet til å fokusere på enkelte etiske problemområder som oppstår når kriser, ulykker og katastrofer formidles i fjernsynsnyhetene. Jeg trekker fram eksempler som på den ene siden belyser ofrenes og pårørendes opplevelser av journalistenes opptreden, og på den andre siden utdyper journalistiske metoder som får seerne til å føle seg manipulert og krenket. Drøftingen foregår først og fremst innen en nærhetsetisk ramme. Målet er også å komme med forslag om hvordan ofrene og deres pårørende kan presenteres mer etisk forsvarlig $\mathrm{i}$ katastrofenyheter, slik at etiske overtramp kan unngås. Jeg ønsker å bringe videre den etiske diskusjonen ved å presentere lite diskuterte etiske innfallsvinkler som springer ut fra mine egne erfaringer som fjernsynsjournalist og medieforsker. 


\section{Medieetiske tilnærmingsmåter}

Medieforskere skiller vanligvis mellom tre hovedmåter å tenke etikk på: utilitarisme, deontologisk etikk og dydsetikk. Utilitarismen er en formålsorientert teori som vektlegger resultatet og maksimerer nytten for berørte parter. Overført til nyhetssendinger er det formålet, nytten, resultatet som blir de sentrale verdier som skal realiseres. Medieetikken har hentet grunnlagstanker fra utilitarismen, men ifølge Oltedal (2006) er denne typen etikk utilstrekkelig. Nyttehensyn og hensynet til det å ta vare på enkeltmenneskets verd kan komme på kollisjonskurs i den praktiske mediehverdagen. Utilitaristisk etikk gir ikke godt nok vern mot misbruk av enkeltmennesket. Den ivaretar ikke tilstrekkelig menneskeverdet og likeverdet til individer og minoriteter i nyhetssendinger. For å ivareta disse kravene trenger journalisten en etisk tenking som ikke bare vektlegger nytten eller formålet ved å bruke mennesket $i$ et program, men som gir veiledning for når formål kan bli til misbruk.

Derfor trenger mediene, ifølge Oltedal (2007), også deontologisk etikk. Den er tuftet på Kants filosofiske idé om at personer aldri skal brukes bare som midler, men samtidig som formål i seg selv. Den deontologiske etikken skiller seg fra den utilitaristiske tenkemåten ved at en går ut fra at spørsmålet om hva som er moralsk rett, ikke kan besvares bare ut fra verdien, nytten eller konsekvensene av en handling. Dydsetikken på sin side er opptatt av hvordan mennesker kan utvikle moralsk dømmekraft. Den som utvikler seg mot dyder som mot, visdom, rettferd og måtehold, vil bli et menneske som handler rett. Ofte vil journalistens etiske vurderinger hente stoff fra alle disse tradisjonene (Oltedal 2006; 2007; Øverbye 2006).

Slik Oltedal $(2006 ; 2007)$ ser det, er medienes viktigste oppgave å utøve deres samfunnsoppdrag. Når journalistene definerer dette oppdraget, viser de ofte til vesentlighetskravet. Det er en journalistisk plikt å få fram fakta og å gi en saklig og pålitelig framstilling i vanskelige saker, som i katastrofenyheter. Ved siden av vesentlighetskravet er nærhetskravet er et av de sentrale nyhetskriteriene (Njaastad 2004), og det er dette kravet som kan misbrukes når det gjelder menneskeverdet i katastrofenyheter. Mediene søker å finne en person som publikum kan identifisere seg med. Dette kan bli et instrumentelt krav om å finne et menneske «som går gjennom ruta» (Oltedal 2007: 94). Mennesket kan bli redusert til en illustrasjon og brukt slik at han eller hun føler seg misbrukt. Samtidig kan publikum føle seg brydd og uvel.

\section{Nærhetsetikk som rettleder}

Siden de tre tidligere nevnte etikktradisjonene ikke synes å gi en tilfredsstillende medieetisk veiledning når det gjelder enkeltmenneskenes integritet $\mathrm{i}$ katastrofenyhetene, har enkelte medieforskere sett nærmere på nærhetse- 
tikkens muligheter som verktøy i etiske vurderinger av nyheter. I denne artikkelen bruker jeg som utgangspunkt norske medieforskernes fortolkninger av den franske filosofen Emmanuel Levinas' (1995) og den danske filosofen Knud Løgstrups nærhetsetikk. Levinas (1995) tar utgangspunkt i «ansiktet» til et enkeltindivid, til den Andre. Møtet med den Andres ansikt utløser en appell som kaller på vårt ansvar for ikke å krenke et medmenneske, men møte ham eller henne med respekt og ydmykhet. Ifølge Levinas må vi møte den Andre med en holdning som er preget av omsorg og ansvar, og ikke misbruke makt eller utnytte hans eller hennes sårbarhet. Ansvaret aktiviseres i relasjoner med en annen, i møtet med medmennesket, den Andre. Når vi står ansikt til ansikt med et annet menneske, blir vi ansvarlige for ham eller henne. Ved et møte med den Andre kan verken journalisten eller seeren unndra seg ansvaret for medmennesket (Rasmussen 2007; Vetlesen 1996).

Den etiske fordringen i Løgstrups (1991) tenkning, slik Oltedal (2007) ser det, er preget av grunnholdningen, «den gylne regel»: Det du vil andre skal gjøre mot deg, skal du gjøre mot dem. Løgstrup trekker fram egenskaper som menneskenes sårbarhet og avhengighet av hverandre. I møtet med et annet menneske blir vi utlevert til hverandre, og det innebærer både makt og gjensidig avhengighet. Enhver relasjon er en maktrelasjon, og gjensidighet forutsetter to likeverdige parter. Dette er et vanskelig dilemma mellom en journalist og en intervjuperson. Mennesker uten medieerfaring kan ikke agere i mediene på lik linje med rutinerte journalister, og forholdet mellom journalisten og intervjupersonen er ikke et gjensidighetsforhold i en intervjusituasjon. Den journalistiske medvirkningen på skjermen foregår ikke mellom jevnbyrdige parter. I dette henseende kommer nærhetsetikken til kort.

Måten Levinas og Løgstrup tenker etikk på, gir, etter Oltedals (2007) mening, verdifullt materiale til medienes møte med mennesket. Løgstrup ser at den enkeltes livsforståelse, selvinnsikt og empati kan bidra til å møte et medmenneske i en likeverdig gjensidig relasjon - det etiske kravet til meg som menneske får jeg i møtet med den Andre. Men hva gjør at denne forståelsen av den Andre kan være anvendelig i journalistens møte med sin intervjuperson? For begge er møtet med medmennesket «etikkens stad». Anvendt på mediene blir etikkens «stad» det som skjer i journalistens møte med mennesker i sitt arbeid. Etikken er grunnleggende i samværet med den Andre, og de etiske kravene er som en fordring og en appell som er implisitt i selve møtet med medmennesket.

Hos Løgstrup (1991) er tillit og makt nøkkelbegrep. Menneskelige relasjoner er maktrelasjoner. Makten viser seg direkte i samværet mellom mennesker og indirekte gjennom handlinger overfor andre mennesker. Kravet om tillit er også sentralt i dette forholdet. I all kommunikasjon ligger makt, og misbruk av makt kan derfor forstås som misbruk av tillit. Oltedal (2007) 
hevder at journalistene ofte ikke ser hvor stor makt de har til å påvirke og gripe inn i andre menneskers liv. Nærhetsetikkens vektlegger det ansvaret som ligger i møtet med den Andre, journalisten kan ikke bare bruke et enkeltmenneske som et godt «case» $\mathrm{i}$ fjernsynet. Skal mediene ha legitimitet i sitt arbeid, må journalisten arbeide for at denne tilliten og troverdigheten opprettholdes. De fleste journalistene opplever situasjoner der det oppstår konflikter mellom den profesjonelle journalistrollen med sine krav og ønsket om å vise medmenneskelighet (Olsen et al. 2008).

\section{Presseetisk katekisme}

De journalistiske idealene i medieetikken er uttrykt i Vær Varsom-plakaten (VVP), som er en presseetisk «katekisme», et sett av yrkesetiske regler. Den beskriver medienes idealer, men sier lite om hvordan idealene utøves i det virkelige liv, påpeker kriseforskerne (Olsen et al. 2008). Selv om den gir retningslinjer for journalistene i deres arbeid, er det mange gråsoner der de må bruke sin egen dømmekraft for å avgjøre hva som er riktig og galt. Personvernet, det å ta hensyn til og erkjenne at offentlig omtale kan skade den enkelte, har tradisjonelt vært presseetikkens primære mål. Det er en medieetisk oppgave å vurdere når skadevirkninger og lidelser er større enn verdien av omtale. Informasjonskravet settes opp mot kravet om å vise hensyn (Brurås 2006). VVP er utarbeidet og vedtatt av Norsk Presseforbund og skal fremme den etiske standarden i mediene samt styrke og verne ytrings- og informasjonsfriheten. Pressens Faglige Utvalg (PFU) overvåker den etiske og faglige standarden i mediene og vurderer etiske overtramp. Hvordan journalistene har oppført seg i forhold til ofrene, kan utprøves i $\mathrm{PFU}$, som vurderer borgernes klager på mediene (Oltedal 2006).

Jeg er enig med Oltedal (2007) som hevder at et problem med medieetikken er at den er for snever, ofte redusert til en diskusjon om ytringsfrihet kontra personvern. Det sentrale spørsmålet er ofte hvor langt man kan gå uten å skade den enkelte i mediene. Journalistene setter lett likhetstegn mellom etikk og det å ikke å gjøre feil, dvs. bli «dømt» i PFU. En etikkoppfatning som innebærer at etikk er et fravær av overtramp, kan bli forsterket av praktiseringen av dagens presseetikk. VVP ligger til grunn for «dommene» i PFU, og en frifinnelse blir lett forstått av journalistene dit hen at etikken var i orden. Dette er en etikkforståelse som oppmuntrer til regelorientering og juridifisering av medieetikken, ifølge Oltedal. Journalist Morten Øverbye (2006) og medieforsker Lars Arve Røssland er enige i at måten selvjustis, dvs. PFU-systemet, fungerer på, kan forsterke en snever regelorientert etikkforståelse. Systemet bidrar lite til en bred etisk refleksjon, siden uttalelsene har lite substans og ofte er tuftet på enkeltstående paragrafer i VVP. 
Selv om de etiske prinsippene er slått fast i VVP, står enkelte journalister i praksis for andre verdier, noe som springer ut av en intens konkurransesituasjon fjernsynskanalene imellom. ${ }^{1}$ Reporter Fredrik Græsvik innrømmer at kynismen i TV-bransjen er utbredt, og journalistene har en tendens til å tøye de etiske reglene for langt:

Det er ekstremt mange kynikere i denne bransjen her. Eller man blir det hvis man ikke er det. Fordi det er ekstrem konkurranse, og du opplever til tider spesielt i fjernsyn fokusering på deg selv som reporter. Hvis du er veldig kynisk og gjør en del valg som er kontroversielle, får du mye plass på tv [...]. Jeg tror at etikken er grei. Jeg tror at det er verre med moralen. Jeg tror virkelig at en del mennesker setter sin egen karriere langt foran moralen [...]. (Hansen 2004: 102)

De etiske normene i VVP fungerer i utgangspunktet som et nyttig verktøy for journalistene, såframt de følger opp intensjonene i plakaten. Problemet oppstår når plakaten fortolkes for snevert, eller journalistene ignorerer de presseetiske kjørereglene. Etikken ligger latent i journalistens arbeid. Den er innvevd i deres virkelighetsoppfatning, profesjonsforståelse, prioritering og redigering av stoff. Den gjør seg gjeldende ved valg av metoder, språkbruk og nyhetsdramaturgi, for å nevne noen faktorer. Da er det en utfordring i en intens konkurransesituasjon å velge bort de salgsfremmende elementene som går på akkord med etisk journalistikk.

\section{Varsomhet eller formynderi?}

Vær Varsom-plakaten maner til forsiktighet i forbindelse med reportasjer fra ulykker og katastrofer:

Vis særlig hensyn overfor personer som ikke kan ventes å være klar over virkningen av sine uttalelser. Misbruk ikke andres følelser, uvitenhet eller sviktende dømmekraft. Husk at mennesker i sjokk eller sorg er mer sårbare enn andre. (Vær Varsomplakaten, punkt 3.9.)

Denne paragrafen er aktuell i forbindelse med ulykker og katastrofer der mennesker er involvert som ofre, øyenvitner eller pårørende. Barn, psykisk utviklingshemmede og personer med alderdomssvekkelse eller sviktende dømmekraft har tradisjonelt hørt til de sårbare gruppene. Men også mennesker med vanlig dømmekraft kan komme i situasjoner hvor media må vise aktsomhet. Journalister er ofte til stede først, og før de skadede har fått medisinsk hjelp, kan de intervjue ofre og pårørende som er i sjokk. Slike intervjuer skjedde for eksempel i forbindelse med terroraksjonen i New York 11. september 2001, tsunamikatastrofen i Sørøst-Asia julehelgen 2004 og skolemassakren i Beslan 2004, der sjokkskadede barn og svekkede eldre ble intervjuet. De unge i det offentlige rom må, på lik linje med voksne, ha 
et krav på å få holde sin sorg og fortvilelse utenfor nærgående kameralinser (Brurås 2000).

Som førstehåndskilder er de overlevende og pårørende viktige kilder for mediene, siden de kan gjenfortelle hendelsen og formidle umiddelbare opplevelser. Det forutsetter at disse personene har kontroll over situasjonen. Selv om de pårørende kan stille opp frivillig, er det journalistenes ansvar å vurdere om personer fremdeles er i sjokk og dypt inne i sorgprosessen. De involverte eller pårørende kan oppleve mediefolkets opptreden som en ekstra påkjenning i tillegg til sjokket, sorgen og traumene. Enkelte personer kan bli medienes ofre to ganger: først gjennom omtale i mediene, deretter ved at pågående journalister utløser en traumatisk opplevelse når ofrenes og de pårørendes privatsfære invaderes av fotografer som er for nærgående (Kolstad 1994; Richards 1998). Mediene kan skape en traumatisk opplevelse for de involverte, som må utlevere sine mest private sinnsstemninger i full offentlighet (Kallevik 2004).

Brurås (2005) hevder likevel at det journalistiske uttrykket «å beskytte mot seg selv» er både nedlatende og arrogant, siden det kan innebære at journalistene på sviktende grunnlag kan frata et menneske retten til å ytre seg. Hvem er berettiget til å opptre som formynder på intervjuobjektets vegne, spør han. Som fjernsynsjournalist har jeg opplevd situasjoner der intervjuobjekter med psykiske eller sosiale problemer åpenbart ikke har vært klar over konsekvenser av sine uttalelser. Unntaksvis har jeg da valgt å «beskytte ham eller henne mot seg selv» fordi etter min mening kan ikke journalisten fratas det etiske ansvaret i en slik situasjon.

Nærgående journalistikk med bl.a. helikoptre som zoomer inn i soverommene til drapsofre har skapt sterk medieetisk debatt i Norge. Et eksempel på dette er den såkalte Hedrum-saken ${ }^{2}$ fra august 1999. Den drepte 12årige Kristin Juel Johannessens familie og nærmiljø i den lille bygda ble invadert av seks helikoptre med telelinser og av 50 journalister, mange av dem slo leir utenfor hjemmet for å dekke saken. Naboene og slektninger måtte rigge opp telt utenfor huset til familien for døgnkontinuerlig vakt mot pågående journalister. Etter drapet utarbeidet forskerne Svein Brurås og Lars Arve Røssland (2000) en rapport om journalistenes fremgangsmåte og opptreden i Hedrum-saken. Rapporten konkluderte med at det skjedde flere etiske overtramp under det journalistiske arbeidet (Røssland 2007). I 2001 ble VVP endret, slik at barns presseetiske vern ble mer konkretisert, og at mediene skulle være forsiktig i omtale av barn og ta hensyn til hvilke konsekvenser medieomtalen kan få for barnet. ${ }^{3}$

Men det ikke bare de involverte som kan føle seg krenket, det kan også publikum. Ifølge resepsjonsundersøkelser av nyheter (jf. Healey 2000; Nightingale et al. 2000) opplever publikum stadig mer støtende nyhetssendinger på fjernsynet. Seerne nevnte først og fremst bilder av døende mennesker, mennesker som er brakt ut av balanse, og fråtsing i voldelig innhold, 
noe som er spesielt uegnet for unge seere. Andre klager gjaldt måten nyheter blir presentert på, for eksempel påtrengende reportasjeteknikker, forstyrrelse av privatlivet og sensasjonelt, overdrevet innhold. De spurte mente også at fjernsynsnyhetene viser fram bilder og intervjuer som mangler sensitivitet overfor pårørende og overlevende. Nyheter som er særdeles oppskakende og gjør et sterkt inntrykk på barn, er detaljerte, autentiske skildringer av drap. Barn reagerer sterkest på bilder der de voksne har mistet kontroll over situasjonen, slik som det skjedde både i Sørøst-Asia og Beslan. Foreldreløse barn som vandrer alene blant ruiner, er de verste nyhetsbildene som kan vises til barn (Nightingale et al.2000, Vettenranta 2005).

\section{Lidelse som markedsstrategi}

Katastrofenyheter skildrer plutselige, omfattende dramatiske hendelser hvor mange mennesker berøres, skades eller omkommer. Terroraksjoner ${ }^{4}$, naturkatastrofer ${ }^{5}$, menneskeskapte katastrofer ${ }^{6}$ og store ulykker ${ }^{7}$ hører til denne kategorien. Krisenyheter kan også dreie seg om dramatiske hendelser som innebærer store psykiske påkjenninger for de involverte. Barnedrapssaker ${ }^{8}$ er i denne kategorien, og i Norge er den mest omtalte nyheten barnedrapene i Baneheia. Mediene er blitt kritisert pga. journalistenes nærgående opptreden overfor pårørende og skadde samt sensasjonspreget personfokusering i forbindelse med flyulykkene i Brønnøysund ${ }^{9}$, i Hirtshals ${ }^{10}$ og brannen på Scandinavian Star ${ }^{11}$ (Brurås 2006). I reportasjene fra skolemassakren i Beslan ${ }^{12}$ viste man opptak av halvnakne og blodige barn som sprang i terroristenes kuleregn i en hasardiøs flukt fra den minelagte skolen. Bildebruken ble kritisert for at journalistene hadde utnyttet og formidlet pårørendes sorg og fortvilelse på en uakseptabel måte (Vettenranta 2005). Jakten etter seertall har tvunget mediebedriftene til å produsere nyheter som i økende grad sjokkerer, forskrekker, opprører og pirrer, ved at de bruke menneskelig lidelse som et salgsfremmende virkemiddel (Graham 1998).

Mediene er også til stede ved minnehøytideligheter og begravelser etter større ulykker og katastrofer. Ved hjelp av avansert teknisk utstyr og telelinser kan fotografene penetrere privatsfæren og zoome inn nærbilder av de sørgende. I overføringene fra minnestundene og begravelsene etter drapene på de to jentene fra Baneheia ble nærbilder av sørgende og gråtende barn og ungdom brukt som illustrasjoner på sorg og fortvilelse. De unges smerte ble brukt som dramaturgisk effekt i fjernsynsnyhetene på en måte som kan oppleves som medieetisk problematisk. Barn i tidlig ungdomsalder er opptatt av ikke å skille seg ut eller miste kontroll over følelser. I den sårbare fasen kan formidling av fortvilelse og angst på TV-skjermen medføre en ekstra belastning. Seremoniene med gråtende foreldre og skolekamerater 
etter Baneheia-drapene påvirket de unge sterkt i min undersøkelse (Vettenranta 2005). Flere av dem brukte uttrykket «ekstremt sterkt» om sine inntrykk, mange fikk kvalmefølelse og tårer i øynene under nyhetssendingen. Å bruke et menneske som et middel for å oppnå en dramaturgisk effekt, for eksempel nærbilder av personer som viser sterke følelsesutbrudd uten vedkommendes samtykke, er etisk uansvarlig, spesielt når dette mennesket ikke har kontroll over sine følelser (Brurås 2006).

Den medieetiske grensen ble også overskredet enkelte ganger i fjernsynsnyhetene fra flodbølgekatastrofen i Sørøst-Asia i 2004. Seerne burde ha sluppet å se en gravemaskin kaste jord over nakne og sønderrevne kropper. Å vise lik, kroppsdeler i nærbilde eller det nakne ansiktet på døde er å profitere på lidelse, skriver den amerikanske forfatteren Susan Sontag (2004). Sontag (2004: 40) påpeker at ved å se et nærbilde «[...] får man skammen i tillegg til sjokket». Seerne opplever at medmennesker på skjermen blir utsatt for urett og ydmykelse i åpenbart krenkende situasjoner, uten at de selv kan gripe inn. Et eksempel på et uverdig bilde ble vist i forbindelse med Estonia-skipsforliset. Det viser en død kvinne kledd i undertøyet som henger i redningswiren under et helikopter (se Raittila 1996). Kvinnens pårørende og medpassasjerer i redningsflåten kjente igjen henne og var vitne til hennes død (Olsen et al. 2008). Mange journalister selv mente at dette var katastrofepornografi.

Gravemaskinbildene fra Sørøst-Asia er også en krenkelse av mennesker fra andre kulturer. Det dreier seg om det siste hvilestedet for mennesker med en annen hudfarge, kultur og religion. Det er utenkelig at norske flomofre ville blitt kastet delvis nakne og maltrakterte inn i et grustak på samme måten. Sontag (2004) hevder at det ifølge journalistisk sedvane har vært akseptert å vise alvorlig sårede og døde kropper i Asia og Afrika i nyhetene. Dette er en arv fra kolonitiden, da afrikanere og innbyggere i asiatiske land ble vist fram som dyr i en dyrehage. Å vise bilder av lemlestede mennesker med en annen hudfarge enn vår egen er å videreføre dette utstillingsaspektet. Ifølge Vær Varsom-plakaten skal journalisten vise respekt for menneskers egenart og identitet, privatliv, rase, nasjonalitet og livssyn, og reportasjene fra Sørøst-Asia syndet her. Den norske medieforskeren Elisabeth Eide (2005; 2006) har gjennom sin forskning dokumentert diskrimineringen mellom vestlige og ikke-vestlige ofre i katastrofenyheter. Medfølelsen og empatien synes å minke med den geografiske avstanden (Olsen et al. 2008).

\section{Katastrofenyheter som underholdning}

En synsvinkel som sjelden diskuteres ut fra et etisk ståsted, er den økende underholdningstendensen i nyhetene. Nyhetsformidlingen har nærmet seg fiksjonsformatene, og av og til er det bare små forskjeller mellom action- 
film, dramatiserte dokumentarprogrammer og sensasjonelt framstilte katastrofenyheter (Buckingham 2000). Flere medieforskere (Bell 1991; Lehtonen 2004; Lindholm 2004) har hevdet at nyhetsdramaturgien har utviklet seg i retning av tematiske narrativer eller nyhetsnoveller. Nyhetene er tilpasset fiksjonens form, der død, personlige tragedier og konflikter spiller en viktig rolle. Behovet for å skape drama presser journalistene til å komponere en fortelling der konflikten mellom «det gode» og «det onde» er bakt inn i framstillingen. Underholdningsfaktoren forsterkes av medienes dramaturgiske behov for å bruke helter og skurker i krigsnyheter, blant annet har Eide (2005) gjennom sin forskning gitt en rekke eksempler på dette. Kulturjournalist Magne Lindholm (2004: 117) har merket seg at enhver nyhet må romme en historie, og nyhetsfortellingen formes som et forløp av hendelser, plassert «[...] i et moralsk univers av helter og skurker, seire og tap».

Dette er ikke overraskende siden fortellingen og narrativ struktur kjennetegner nyheter. Når nyhetene nærmer seg underholdning, forvitres medienes samfunnsperspektiv og journalistenes samfunnsoppdrag (BechKarlsen 2006). Det menneskelige ansiktet brukes stadig oftere til å iscenesette «skurken» og «helten» og dermed true menneskenes integritet ved demonisering og glorifisering. Nyhetsinnslagene bearbeides for seerne, og vi må problematisere hvordan bearbeidingen skjer samt hvilke vurderinger og dramaturgiske strategier som ligger bak tilretteleggingen av det medieskapte virkelighetsbildet. I tillegg til å ordne virkeligheten for oss, tilbyr nyhetene også en norm for hvordan verden skal oppfattes og fortolkes. Således har nyhetene etiske implikasjoner for seerne (Foss 1988).

Den franske sosiologen Pierre Bourdieu (1998) hevder at fjernsynsnyheter presenterer verden som en absurd serie av katastrofer som verken kan forstås eller påvirkes, som uendelige parader av etniske kriger, vold og kriminalitet. De bidrar ikke til mobilisering eller politisering, men øker heller fremmedfiendtlighet, skaper fatalisme og manglende engasjement. Ofte er enkeltnyheter avsondret fra sin sammenheng, og nyheter om samfunnsforhold ligner nyheter om tornadoer, skogbranner og flomkatastrofer. Medieforsker Terje Rasmussen (2007) påpeker at faren med fiksjonaliseringen og underholdende nyheter kan være at seeren ikke trenger å ta mer innover seg enn en film som Schindlers liste eller Missing.

Et annet etisk betenkelig aspekt er at fjernsynet kan estetisere nyheter ved hjelp av redigeringsteknikker. Katastrofeestetikk er forholdsvis nytt i journalistikken, med Golfkrigen i 1991 som det første tydelige eksempel på denne trenden. Krigsreportasjene lignet på science fiction og avanserte PCspill, og amerikanske jagerpiloter opplevde bombingen av Bagdad som et opplyst juletre eller et fargerikt fyrverkeri. Bildene fremstilte lite blod og lemlesting, viser medieforsker Svein Østeruds (1991) analyse. En slik avstandsskaping fratar seerne muligheten for å føle empati med ofrene 
(Rasmussen 2007). Parallelt med nærgående reportasjer med døende og sårede mennesker løper altså en annen type nyhetsrapportering som skildrer kriger og katastrofer uten smertelige sekvenser eller identifiserbare ofre. Nyheter ligner en impressionistisk film der publikum kan lene seg tilbake i en slags nummen følelse av å bli underholdt (Vanhanen 1998).

Den finske medieforskeren Pentti Raittila (1996) presenterer enda et eksempel på manipulerende redigeringsteknikker, der man komponerte en romantisk fortelling om Kent og Sara, overlevende etter Estonia-katastrofen. Selv om de to ble intervjuet i forskjellige land, skapte nyhetssendingen Aktuellt i det svenske fjernsynet ved hjelp av dramaturgiske midler, kryssklipping, løsrevne intervjusitater og fiktive elementer en oppfatning av at de to satt sammen og smilte ømt til hverandre. Kent og Sara, ulykkens personifiserte helter, ble på en manipulativ måte brukt til å representerte den romantiske ideen om kjærlighetens triumf over døden. Dette var klart et medieetisk overtramp, siden publikum ikke ble gjort oppmerksom på sakens fakta.

Nyheter beveger seg på et kontinuum, der reportasjene i den ene enden benytter seg av pågående nærbilder med smerte og blod til avstandskaping og teknifisering i den andre enden. Begge ytterpunktene er medieetisk kritikkverdige. Estetisering av krigsnyheter og usynliggjøring av ofrene fratar seerne muligheten til å oppleve empati med de rammede. Nærbilder av døde med ødelagte ansikter og avkappede lemmer fratar de døde verdigheten. Den etiske forsvarlige journalistikken plasserer seg et sted midt på kontinuumet, der publikum kan identifisere seg med medmennesker eller ofre uten at dette oppleves krenkende. Her er journalistens skjønn avgjørende.

\section{Medlidenhet som programkonsept}

Fjernsynet velger ofte et barneansikt for å personifisere lidelser og vekke medfølelse hos seerne. I fjernsynsnyhetene fra krigene i Bosnia og Irak ble mange enkeltbarn løftet fram, slik som den lille Irma i Sarajevo, ${ }^{13}$ noe som utløste humanitær hjelp verden over i 1993. Navngitte barn illustrerer at hjelpen kom fram til det barnet som tilfeldigvis hadde kameraet rettet mot seg, mens barn ved siden av forble ukjente ofre uten hjelp (Rasmussen 2007). Sultende barn brukes som standardbilder når en rapporterer om flyktninger og hungersnød (Moeller 1999), og bruk av barneansikt som virkemiddel kan spores tilbake til de første store katastrofenyhetene som ble overført på fjernsyn. Gråtende barn med oppsvulmede mager og spinkle lemmer under hungersnøden i Afrika på 1980-tallet ble et vendepunkt i mediebildet. «Biafra-barn» ble symbol på uskyldige ofre, på samme måten som den nakne piken som sprang under napalmregnet i Vietnam i 1972. Medlidenhet er ett element i nyhetenes programkonsept, i den globale med- 
lidenhetsdiskursen. Boltanski (1999) kaller dette fenomenet «politics of pity». Her brukes barn som middel i en nyhetsdramaturgi, ikke som mål nærhetsetisk forstått.

Samtidig øker faren for å bli likegyldig for smerten, noe medieforskerne har påpekt, blant annet Moeller (1999). En slik forenklet nyhetsstrategi kan i lengden virke mot sin hensikt ved å lede til medlidenhetsutmattelse. Sontag (2004) hevder at bildene mister sin kraft ved måten det brukes på og etter hvor ofte de vises. Seeren oversvømmes av bilder som tidligere skapte sjokk, men som de senere knapt reagerer på. Likegyldighet har sin opprinnelse i den flakkende oppmerksomheten og den overfloden av bilder som kjennetegner fjernsynet.

Det er også etisk betenkelig at både kvinner, barn og eldre ofte framstilles i katastrofenyhetene som passive tilskuere, uten en aktiv aktørrolle. Deres rolle er nærmest dekorativ, gråtende og lidende blant krigsruiner, slik den finske medieforskeren Irma Kaarina Halonen (1998) har vist i forbindelse med hendelsene på Balkan på 1990-tallet. Fra skolemassakren i Beslan, Nord-Ossetia i 2004 ble det produsert nyhetsbilder som konsekvent brukte kvinner, barn og eldre som «nyhetsrekvisita»(Vettenranta \& Hohr 2007). Man kan si at kvinner brukes som virkemidler for å illustrere emosjoner i en patriarkalsk nyhetsstereotypi. Den norske medieforskeren Berit von der Lippes (1999) forskning har vist hvor sterkt nyheter er preget av maskuline verdier og referanserammer. Den kjønnsmessige ubalansen i krigsreportasjene er godt dokumentert: Menn er aktører, mens kvinner, barn og eldre blir fremstilt som ofre. Også Eide (2005) har gjennom sin forskning vist marginalisering av både kvinner og minoriteter. Marginalisering betyr tilsidesetting og usynliggjøring av enkeltmenneskers erfaringer og innsats, noe som ut fra etisk ståsted kan tolkes som å bryte ideen om menneskers likeverd.

En annen presentasjonsform, avstandsstrategien, avskaller det emosjonelle materialet i katastrofenyheter ved at nyheter omhandler mennesker som store masser. Helikopterbilder av flyktningeleirer, flomkatastrofer og hungersmarsjer hører til denne kategorien. Karakteristisk for nyhetsbildene er massenes anonymitet, som Halonen (1998) kaller det. Nyhetene viser et bilde av tusen knappenålstore menneskehoder, slik at det blir umulig å identifisere seg med de lidende. Avstanden tåkelegger det etiske ansvaret som oppstår for den Andre i ansikt-til-ansikt-relasjonen. Rasmussen (2007: 62) peker på at selv om fjernsynet viser krigens og katastrofenes ofre, demper avstanden og kameraets dramaturgi sjokket. Det er vanskelig å foreta det empatiske spranget, for seeren kjenner avmakt, ubehag og handlingslammelse.

Rasmussen (2007) hevder at møtet med medmennesket på skjermen, den Tredje, da kan bli overfladisk, uten at en ekte medfølelse mobiliseres. Han spør om medmenneskelig ansvar kan overskride medienes avstander, 
og om fjernsynsansiktet kan skape tilstrekkelig empati til at seerne kan føle etisk forpliktelse overfor lidende mennesker på skjermen. Rasmussen undrer videre på om nærhetsetikk kan omfatte de medmennesker som bare kan betraktes gjennom mediene, og om mediene klarer å formidle ansvar for mennesker som opptrer som statistikk eller som abstrakt viten. Hvis fjernsynsnyheter makter å engasjere publikum på et moralsk grunnlag, må to betingelser må være oppfylt: For det første må publikum kunne delta i en dialogisk relasjon til mediets budskap, og for det andre må publikum oppleve budskapet som sannferdig og saklig. Resepsjonsstudier synes å påvise et slikt dialogisk forhold, publikum kan engasjeres følelsesmessig i forhold til skjermen (Nightingale et al. 2000; Tester 1994; Vettenranta 2005). Når det gjelder sannferdighet og saklighet, kan fiksjonaliseringen og kommersielle underholdningstendenser undergrave etisk nyhetsformidling.

Slik Rasmussen (2007) forstår Levinas, vekker den umiddelbare Andre ikke bare et ansvarsforhold, men også et solidaritetsforhold som gjelder meg og de fraværende Andre, dvs. ukjente fjernsynsansikter. Da sees den umiddelbare Andre som en representant eller en påminnelse om de mange andre som jeg også har et ansvar for. Den Andre i vår nærhet gir dem et ansikt. Handlinger, for eksempel i den journalistiske praksis, kan gjøres i analogi med et direkte møte. Rasmussen hevder imidlertid at Levinas' forsøk på å la den Andres ansikt stå som representant for den Tredje, dvs. fjernsynsansiktet, virker lite overbevisende.

\section{Kan lidelsen formidles etisk?}

En viktig utfordring for journalistene under katastrofer er å skille mellom den private og den offentlige sorgen. Journalist Arne Blix og medieforsker Jo Bech-Karlsen (1990) har presentert metoder for formidling av sorg i katastrofesituasjoner. De anbefaler at journalistene ikke spekulerer i tårer og heller bruker symboler i form av gjenstander som kan knyttes til den omkomne. Dette kan riktignok i enkelte situasjoner oppleves uetisk når private hilsener til den omkomne sendes i nærbilder, for eksempel i reportasjene fra barnedrapssakene der barnas sorgbrev blir vist til publikum. Dekning i bredde fremfor nærhet er å foretrekke. Under en sorgseremoni bør journalistene unngå å blotte den enkeltes private fortvilelse og sorg, og heller «[...]formidle den samhold og fellesskap som sorgen skaper mellom de sørgende, den verdighet de makter å skape rundt markeringen på tross av sin fortvilelse» (Blix \& Bech-Karlsen 1990: 194).

Blix og Bech-Karlsen (1990) foreslår videre å bruke dynamiske i stedet for statiske bilder, slik at kameraet ikke unødvendig dveler med forpinte ansiktsuttrykk, den såre gråten og de hjelpeløse blikkene. Publikumsforskningen (Healey 2000; Moeller 1999; Nightingale et al. 2000) tyder på at 
mange seere ønsker å avvise en slik intimterror, og at de føler ubehag ved visning av andre menneskers private sorg. Blix og Bech-Karlsen hevder at statiske, dvelende bilder ikke gir en dypere forståelse av katastrofen og foreslår at den sørgende personen plasseres midt blant andre sørgende for å gi bildet bedre dynamikk. Bilder som viser sorgfelleskap, viser ikke bare fortvilelse, men gir håp for framtiden. Veksling mellom bredde og nærhet, dynamiske og statiske uttrykk, er en vanskelig balansegang. Journalistene må utvise skjønn i hver enkel situasjon. Anonymisering er en mulighet, men i praksis må journalisten ofte velge mellom anonyme personer med sterk historie eller en sterk historie med anonyme personer (Øverbye 2006).

Nyhetsjournalistikkens etiske idealer kan være vanskelige å oppfylle i en katastrofesituasjon. Det profesjonsetiske dilemmaet oppstår når publikum har krav på å vite om ulykken. Mediene skal informere publikum, samtidig som de skal være kritisk granskende og hensynsfulle med tanke på personvern. Å oppfylle samtlige krav kan være utfordrende for journalister under kriser og katastrofer. De berørte befinner seg i en unntakstilstand, og journalistene arbeider under stort fysisk, psykisk og tidsmessig press. Avgjørelser må tas raskt i en ekstrem situasjon, og da er journalistens etiske «ryggmargreflekser» avgjørende. Under en katastrofe får også journalistene reaksjoner som nummenhet og sjokk, redusert tankekapasitet, hjelpeløshet, fortvilelse, sorg, angst, sinne og fysiske reaksjoner. En slik mental tilstand reduserer muligheten til å gjøre en best mulig etisk fundert jobb i en akutt krisesituasjon (Blix \& Bech-Karlsen 1990; Olsen et al. 2008).

Medienes nærhetskrav står sentralt i nyhetsjournalistikken siden det er viktig at seerne har en person å identifisere seg med. Når mediene bruker enkeltmennesker for å skape identifikasjon, kan disse menneskene lett fremstå som illustrasjoner, redusert til objekter i reportasjen. Det kan det lede til en instrumentell holdning til mennesket, noe Oltedal (2007) peker på. Brurås (2005) er inne på det samme: Å utnytte enkeltmenneskets sorg og tårer som dramatisk effekt $\mathrm{i}$ en «sterk» fortelling betyr at mennesket reduseres til et virkemiddel. Her er et journalistisk dilemma - mediene blir på den ene siden kritisert for å være for personorienterte, men samtidig er personorienteringen en viktig journalistisk metode. Dette byr på en stadig utfordring for journalistene.

Rasmussen (2001) har et bredere samfunnsperspektiv i etikken enn Oltedal (2006; 2007). Rasmussen ser medieetikk som langt mer enn bare journalistetikk, som Oltedals personorienterte nærhetsetikk representerer. Oltedals nærhetsetiske møte med medmenneske virker som en viktig, men for snever innfallsvinkel til medieetikken. Det oppleves litt naivt å tro at en journalist kan utføre sitt yrke som fullstendig autonom. Journalisten er bundet av profesjonspraksis, journalistiske rammer og taus kunnskap på praksisfeltet, hensynet til arbeidsgiveren, for eksempel en mediebedrift som legger publikumstallet og kommersielle premisser til grunn. Nyheter funge- 
rer som varer på et marked, på lik linje med underholdningsprogrammer (Olsen et al. 2008).

Medieforsker Odd Raaum (1986) er også kritisk til nærhetsetikken som tilnærming og hevder at det er mer vesentlig å fokusere på medieetiske spørsmål på eier- og ledernivået i mediebedrifter. Røssland (2007) støtter oppfatningen av at medieansvaret også bør ligge på dette nivået, men samtidig må den enkelte journalist bære det etiske ansvaret for sitt daglige virke. Raaums påstand om at mennesker som kilder er et middel for å nå et mål, er direkte i strid med nærhetsetikken. Nærhetsetisk tilnærmingsmåte bruker ikke mennesker som et middel, men et mål i seg selv. Den ansvarliggjør personen som handler. Øverbye (2006) hevder at det er lett for journalistene a fraskrive seg ansvaret for konsekvensene ved å skjule seg bak de presseetiske retningslinjene. Den journalistiske profesjonsetikken dyrker den «[...] uavhengige, uberørte, distanserte, kjølige observasjonen av en hendelse og har lite rom for empati, omtanke, innlevelse og medfølelse» (Brurås \& Røssland 2000: 48). En slik ufølsomhet bør ikke bli en profesjonell journalistisk holdning.

\section{Avsluttende kommentar}

Brurås (2006: 301-306) legger vekt på den etiske avgjørelsesprosessen og påpeker at journalisten har et valg før nyhetsformidling. Han stiller åtte spørsmål som er viktige etiske rettesnorer for en journalist som nyhetsformidler: Hva er sakens fakta? Hvem blir berørt av omtalen? Hva er handlingsalternativene? Hva er konsekvensene av disse alternativene? Hvilke verdier og prinsipper står på spill? Hvor plasserer jeg min lojalitet? Hva er vesentlig informasjon for publikum? Tåler mine motiver og metoder dagens lys?

Presseetiske regler er en nødvendig, men ikke en tilstrekkelig forutsetning for etisk nyhetsformidling. Et rigid regelverk kan virke mot sin hensikt fordi det kan redusere journalistens personlige ansvar for sine valg (Brurås 2006). Kritikken mot medienes metoder rettes som oftest mot overtramp, men Brurås undrer seg på om ikke journalistene fortjener mer kritikk for det de ikke gjør:

[...] da vi overså maktmisbruk, da vi ignorerte lidelse og undertrykkelse, da feighet og frykt for konsekvensene avgjorde nyhetsvurderingen, da vår udugelighet og holdningsløshet førte til at urett ble tildekket og de maktesløse ikke fikk komme til orde [...]. (Brurås 2006: 9)

Min doktoravhandling om formidling av Tsjernobyl-katastrofen i 1986 i Norge (Vettenranta 1998) avdekket nettopp slike etiske brister: Myndighetenes maktmisbruk i form av tilbakeholdelse og manipulering av informa- 
sjon, journalistisk feighet som mikrofonstativer og manglende kritikk overfor myndighetene. De maktesløse, i dette tilfelle den hardt rammede sørsamiske befolkningen, kom ikke tilstrekkelig til orde. Formidling av Tsjernobyl-nyhetene demonstrerte således også et manglende nærhetsetisk perspektiv: maktmisbruk, manglende tillit og manglende ansvar i relasjoner mellom myndigheter, journalister og publikum.

\section{Takk}

Takk til redaksjonen og to anonyme refereer for kommentarer til et tidligere utkast av denne artikkelen.

\section{Noter}

1 Kynismen er ikke forbeholdt fjernsynsjournalister, noe som Håvar Melnæs' bok En helt vanlig dag på jobben (2007) om Se og Hørs arbeidsmetoder, bl.a. sjekkheftejournalistikk, viser.

2 «Barneparagrafen», pkt. 4.8. i Vær Varsom-plakanten ble revidert som et resultat av Barneombudets klager og pressens framgangsmåte og opptreden i Hedrum i august 1999 (Øverbye 2006).

3 Etter at VVP ble revidert, har antall brudd mot denne paragrafen økt betraktelig. I perioden 1995-2000 var det seks klagesaker der mediene ble kritisert av PFU. Fra 2001 til 2005, etter den nye barneformuleringen ble innført, er det 23 klagesaker i klagerens favør (Øverbye 2006: 50).

4 F.eks. terrorangrepet mot World Trade Center 11. september 2001, ca. 3000 omkomne.

5 F.eks. tsunamien i Sørøst-Asia julehelgen 2004, ca. 350000 omkomne.

6 F.eks. kjernekraftulykken i Tsjernobyl 26. april 1986. Pga. langtidsvirkninger av radioaktiv stråling varierer antall omkomne.

7 F.eks. Estonia-skipsforliset i Østersjøen 28. september 1994, 852 druknede, eller Linate-flyulykken i Italia 8.10.2001, 118 omkomne.

8 F.eks. barnedrapene i Baneheia. 8 år gamle Stine Sofie og 11 år gamle Lena ble voldtatt og drept i Kristiansand 21.5.2000.

9 Flyulykke i Brønnøysund 6. mai 1988, 36 omkomne.

10 Flyulykke 6. mai 1989, 55 omkomne.

11 Skipsbrann 7. april 1989, 158 omkomne.

12 Skolemassakre i Nord-Ossetia 3. september 2004, 334 drepte, derav 186 barn.

13 Lille Irma var en bosnisk jente som ble alvorlig såret i august 1993 da serberne angrep Sarajevo. Hun ble fløyet til Storbritannia for behandling, men døde av blodforgiftling i et britisk sykehus i 1995. Vetlesen (1996: 158) presenterte Irma-saken, som flere medieforskere har vist til senere. 


\section{Litteratur}

Bech-Karlsen, J. (2006) Intimsfæren i medieoffentligheten. I Medier, politikk og samfunn, red. B. v. d. Lippe, s. 176-208. Oslo: Cappelen Akademisk.

Bell, A. (1991) The language of news media. Oxford: Blackwell.

Blix, A. \& Bech-Karlsen, J. (1990) Hva har vi der å gjøre? Metoder og etikk i katastrofe- og ulykkesjournalistikk. Fredrikstad: Institutt for journalistikk.

Boltanski, L. (1999) Distant suffering: Morality, media and politics. Cambridge: Cambridge University Press.

Bourdieu, P. (1998) On television and journalism. London: Pluto Press.

Brurås, S. (2005) Følelser og fakta. Kronikk Dagbladet, 11. januar 2005.

Brurås, S. (2006) Etikk for journalister. 3. utg. Oslo: Fagbokforlaget.

Brurås, S. \& Røssland, L. A. (2000) Prosjekt Hedrum: Full skjoring - drapssaken, nyhetsjakten og menneskene bak nyhetene. Oslo: Norsk Journalistlag.

Buckingham, D. (2000) After the death of childhood: Growing up in the age of electronic media. Cambridge: Polity Press.

Eide, E. (2006) Journalistikk og marginalisering. I Medier, politikk og samfunn, red. B. v. d. Lippe, s. 243-261. Oslo: Cappelen Akademisk.

Eide, E. (2005) Tsunamien, menneskene og mediene. Norsk medietidsskrift, 1, s. 4861.

Foss, G. (1998) Det nasjonale sorgarbeid. Tid og fortelling i Dagsrevyens beretning om rasulykka $i$ Vassdalen. Trondheim: Universitetet i Trondheim, Den allmennvitenskapelige høgskolen, Nordisk institutt.

Graham, G. (1998) Sex and violence in fact and fiction. I Media Ethics, red. M. Kieran, s. 152-164. London: Routledge.

Halonen, I. K. (1998) Mamma, jag miste handen! Kvinnobilden i krigsnyheter. NORDICOM Information, 4, s. 21-33.

Hansen, T. B. (2004) «Jeg tror ikke Allah ville at de skulle ta selvmord». En kvalitativ undersøkelse om unges resepsjon av terrorangrepet 11. september 2001. Hovedoppgave. Trondheim: Norges teknisk-vitenskapelige universitet.

Healey, J. (red.) (2000) Mass media and society. Issues in society. Sydney: Spinney Press.

Kallevik, S. A. (2004) Journalistikk i krise? Om krisejournalistikk og krisereaksjoner. Kristiansand: IJ-forlaget.

Kieran, M. (1998) Objectivity, impartiality and good journalism. I Media Ethics, red. M. Kieran, s. 23-36. London: Routledge.

Kolstad, T. A. (1994) Medias makt - ofrenes avmakt. Om mennesker og media til ettertanke og refleksjon. Fredrikstad: Institutt for journalistikk.

Lehtonen, M. (2004) Syyskuun yhdennentoista merkitys [Betydningen av 11. september. Orig. på finsk]. Tampere: Vastapaino.

Levinas, E. (1995) Etik og uendelighed. København: Hans Reitzels Forlag.

Lindholm, M. (2004) Det trivielles triumf. Samtiden, 1, s. 115-126.

Lippe, B. v. d. (1999) Metaforens potens. Essays. Oslo: Oktober.

Løgstrup, K. E. [1956] (1991) Den etiske fordring. København: Gyldendal.

Melnæs, H. (2007) En helt vanlig dag på jobben. Se og Hør fra innsiden. Oslo: Kagge forlag.

Moeller, S. D. (1999) Compassion fatigue: How the media sell disease, famine, war and death. New York \& London: Routledge. 
Nightingale, V., Griff C. \& Dickenson D. (2000) Children's views about media harm. Research Report no. 10. Sydney: Australian Broadcasting Authority.

Njaastad, O. (2004) TV-journalistikk. Bildenes fortellerkraft. 2. utg. Oslo: Gyldendal Akademisk.

Oltedal, A. (2007) Etikk og media. I Mediedanning og mediepedagogikk. Fra digital begeistring til kritisk dømmekraft, red. S. Vettenranta, s. 83-104. Oslo: Gyldendal Akademisk.

Oltedal. A. (2006) Etikk og journalistikk. I Medier, politikk og samfunn, red. B. v. d. Lippe, s. 15-19. Oslo: Cappelen Akademisk.

Olsen, O. E., Mathiesen, E. R. \& Boyesen, M. (2008) Media og krisehåndtering. En bok om samspillet mellom journalister og krisehåndterere. Kristiansand: Høyskoleforlaget.

Raittila, P. (1996) Uutinen Estonia. Kriisiviestintä ja journalismin etiikka koetuksella [Nyhet Estonia. Krisekommunikasjon og journalistisk etikk på prøve. Orig. på finsk]. Tampere: Tampere University Press.

Rasmussen, T. (2007) Mennesket på skjermen. I Mediedanning og mediepedagogikk. Fra digital begeistring til kritisk dømmekraft, red. S. Vettenranta, s. 62-82. Oslo: Gyldendal Akademisk.

Rasmussen T. (2001) Mediesamfunnets moral. Oslo: Pax Forlag.

Richards, I. (1998) Ethics: Journalists and victims. I Journalism: Theory and practice, red. M. Breen. Marrickville: Macleay.

Røssland, L. A. (2007) Media og det menneskelege. Moralfilosofiske utgangspunkt for journalistisk etikk. Oslo: Det Norske Samlaget.

Raaum, O. (1986) Pressens tøyelige etikk: Journalistenes yrkesmoral og selvjustis. Oslo: Universitetsforlaget.

Sontag, S. (2004) Å betrakte andres lidelse. Oslo: Pax Forlag.

Stam, R. (1983) Television news and its spectator. I Regarding Television, red. E. A. Kaplan, s. 139-147. Los Angeles: University Publications of America.

Tester, K. (1994) Media, culture and morality. London: Routledge.

Vanhanen, H. (1991) Kuoleman kuvat [Dødens bilder. Orig. på finsk]. Tampere: Tampere University Press.

Vetlesen, A. J. (red.) (1996) Norhetsetikk. Oslo: Ad Notam Gyldendal.

Vetlesen, A. J. (2007) Hva er etikk? Oslo: Universitetsforlaget.

Vettenranta, S. (1998) Making sense of Chernobyl nine years after: TV news reception study of the environmental disaster. Doktorgradsavhandling. Trondheim: Norges teknisk-vitenskapelige universitet.

Vettenranta, S. (2005) De unge og katastrofenyheter. Oslo: Abstrakt Forlag.

Vettenranta, S. \& Hohr, H. (2007) Skolemassakren i Beslan mellom myte og folkeeventyr. NORDICOM Information, 4, s. 71-80.

Vær Varsom-plakaten (2006). I Etikk i journalistikk, S. Brurås, s. 307-320. Bergen: Fagbokforlaget.

Østerud, S. (1991) Krigen som science fiction og døden som sorgritual. I Mediekrigen: Søkelys på massemedienes dekning av Golfkrigen, red. J. Johnsen \& T. Mathiesen. Oslo: Cappelen.

Øverbye, M. (2006) Barn i mediene. Kristiansand: IJ-forlaget. 